\section{A REVIEW OF USING NATURAL RUBBER IN THE MODIFICATION OF BITUMEN AND ASPHALT MIXTURES USED FOR ROAD CONSTRUCTION}

\author{
Abdulnaser Al-Sabaeeia*, Nur Izzi Md. Yussofb, Madzlan Napiaha, \\ Muslich Sutantoa
}

aDepartment of Civil and Environmental Engineering, Universiti Teknologi PETRONAS, 32610, Seri Iskandar, Perak, Malaysia bDepartment of Civil and Structural Engineering, Universiti Kebangsaan Malaysia, 43600, Bangi, Selangor, Malaysia
Article history

Received

18 March 2019

Received in revised form

18 July 2019

Accepted

24 July 2019

Published online

24 October 2019

*Corresponding author abdulnaser_17005477@utp.

\begin{abstract}
A comprehensive review using natural rubber in the modification of bitumen used for road construction is presented in this paper. The sources, types and properties of natural rubber are discussed briefly. The methods used by researchers to add natural rubber as a modifier for bitumen are also discussed. A literature review of the effects of natural rubber on the physical, mechanical and rheological properties of bitumen and the performance of asphalt mixtures over the past three decades is presented along with the cost analysis of using natural rubber as a modifier in comparison to using other polymers. Researchers in the field of the highway and pavement engineering need to find a method to deal with the most common pavement distress by using local additives such as natural rubber. It is expected that a special, cost effective and long lasting natural rubber modified flexible for road pavements, which is also fatigue and rut resistant, will be developed in the near future. This will reduce the amount of expenses required for the annual maintenance of asphalt mixtures around the world.
\end{abstract}

Keywords: Natural rubber, latex, liquid natural rubber, ribbed smoked sheet, natural rubber powder, bitumen

\begin{abstract}
Abstrak
Kajian komprehensif tentang penggunaan getah asli dalam pengubahsuaian bitumen yang digunakan untuk pembinaan jalan dibentangkan dalam kertas ini. Sumber, jenis dan sifat-sifat getah asli dibincangkan secara ringkas. Kaedah yang digunakan oleh penyelidik untuk menambah getah asli sebagai pengubahsuaian untuk bitumen juga dibincangkan. Kajian literatur mengenai kesan getah asli terhadap sifat fizikal, mekanikal dan rheologi bitumen dan prestasi campuran asfalt selama tiga dekad yang lalu disampaikan bersama dengan analisis kos menggunakan getah asli sebagai pengubah suai berbanding dengan menggunakan polimer lain. Penyelidik-penyelidik dalam bidang kejuruteraan lebuh raya dan turapan perlu mencari kaedah untuk menangani kegagalan turapan yang paling biasa dengan menggunakan bahan tambah tempatan seperti getah asli. Dijangkakan bahawa getah asli diubah suai untuk turapan jalan raya adalah istimewa, kos efektif dan tahan lama, yang juga tahan kelesuan dan perpaluhan, akan dibangunkan dalam masa terdekat. Ini akan mengurangkan perbelanjaan yang diperlukan untuk penyelenggaraan tahunan campuran asfalt di seluruh dunia.
\end{abstract}

Kata kunci: Getah asli, lateks, getah asli cecair, lembaran asap lembut, serbuk getah asli, bitumen

(C) 2019 Penerbit UTM Press. All rights reserved

\subsection{INTRODUCTION}

Most of the roads constructed around the world are paved with asphalt mixtures which have better flexibility and are more economical than concrete pavements. Bituminous materials used for road pavements must meet the requirements and standard specifications of the country in which it will be used to ensure that they are suitable, long lasting and highly safe for users. However, asphalt 
pavements have certain limitations in that they crack at high temperature and soften at low temperature [1-5]. Heavy and high loading traffic have been shown to cause early damage to pavements despite its design life, and this will result in higher repair and maintenance expenses. Thus, it is important to find ways to improve the properties of the bitumen in terms of its elasticity and viscosity, temperature susceptibility, softening point, aging resistance and cohesion. Furthermore, there is an urgent need to produce modified bitumen which will improve the characteristics of pavements with regard to fatigue, rutting and thermal cracking resistance [6-10].

Although there are many ways to improve the properties of bitumen, polymer is the most popular and practical additive used to produce "Polymer Modified Bitumen." Many previous studies have proven that PMB significantly improve the performance of asphalt mixtures, thereby extending, the service life of pavements. In particular, PMB improves the stiffness, elasticity, cohesion and adhesion properties of bitumen. These improvements make asphalt mixtures more stable and resistant to rutting, fatigue and thermal cracking at varying temperatures [9, 11, 12]. The use polymers such plastic and rubber materials help to reduce the problem of pollution [13, 14].

Thermoplastic elastomers are among the most well-known polymers used by virtue of their lower prices. These types of polymer have the ability to improve the condition and overall performance of asphalt pavements, especially with regard to rutting resistance. Rubber is one of the polymers used as a modifier to enhance the properties of bitumen, particularly elasticity, stability and fatigue resistance [15-17].

Natural rubber [18] is one of the most common TEs used in binder modification. Following the first application of NR in road construction in Singapore in 1929, many organizations in the UK, USA and South Africa began to study the effects of NR latex on the durability of bitumen in road surface [19]. Natural rubber was observed to have superior reactivity, which improve the properties of bitumen, such as adhesion, in comparison to other types of rubber used in bitumen modification. NR was also observed to have a strong cohesion with aggregates; this increases the stiffness of bitumen at high temperatures, thereby improving the performance of asphalt mixtures [20]. This review will discuss the sources, types, manufacturing processes, and significance of the use of NR in bitumen modification. This will open a new area for researchers in using NR to improve the performance of bitumen under different loading and environmental conditions.

\subsection{WHAT IS NATURAL RUBBER?}

Natural rubber is an elastomer which is derived from the milky latex found in the sap of some plants. The pure form of natural rubber is the chemical polyisoprene. Natural rubber is one of the most readily available polymer and its thermal and binding properties has led to its use in bitumen modification to improve the service life of flexible pavements [21-23]. Natural rubber (Latex) is available throughout the world and is used in large quantities to produce a wide variety of life commodities such as gloves, mattresses, balloons, and swim caps. These commodities should be recycled to prevent them from polluting the environment [21]. The idea of using natural rubber latex began more than 31 years ago when it was used in asphalt surfacing to improve bitumen performance [24]. The use of natural rubber latex is considered as good method for enhancing bitumen properties since it contains natural rubber, and discrete rubber particles can be easily fused with bitumen. In cold weather, natural rubber latex acts as an elastic band which helps to prevent the formation of cracks while maintaining bitumen stiffness. As the temperature increases, natural rubber acts as a film which improve shear resistance which in turn prevents bitumen flow $[25,26]$. It has been generally proven that the use of natural rubber latex significantly improve long-term pavement performance [27].

\subsection{METHODS FOR PREPARING AND ADDING NATURAL RUBBER FOR BITUMEN MODIFICATION}

Raw natural rubber latex is not used directly due to its high water content and its susceptibility to bacteria attack. Several methods have been developed to produce highly concentrated dry natural rubber of $60 \%$ or higher. Centrifugation is more commonly used compared to, creaming and evaporation methods. Ammonia is usually added to protect NR latex from bacteria attack [25]. The content of dry rubber in latex is one of the most important factors determining the properties of latex. Kumara [28] conducted a study in Sri Lanka to illustrate the methods which can be used to estimate dry rubber content (DRC) in natural rubber latex. The properties of natural rubber depend on several factors, such as season, clone, soil conditions, age of the tree, tapping method and the frequency of rubber harvesting, etc. The density of natural rubber latex varies depending on the composition of latex. Table 1 shows the typical composition of fresh natural rubber latex.

Table 1 Typical composition of fresh NR latex [29]

\begin{tabular}{lll}
\hline No. & Parameters & Capability Values \\
\hline 1 & Flight time (minute) & 15 \\
2 & Take-off weight $(\mathrm{kg})$ & $<2.0$ \\
3 & Altitude $(\mathrm{m})$ & $100-300$ \\
4 & Payload $(\mathrm{kg})$ & 0.250 \\
5 & Radio System Frequency & 2.4 \\
& $(\mathrm{GHz})$ & \\
\hline
\end{tabular}


Kumara [28] stated that the density of NRL, which ranges between 0.970 and $0.985 \mathrm{~g} / \mathrm{cm}^{3}$, is mainly due to the DRC in the latex. Of the several methods which can be used to estimate the DRC of latex, the metrolac estimation method is a simple and most convenient method which can be implemented in the field immediately after collecting the latex. It is crucial to know the DRC of NRL so that the correct amounts of chemicals and acid are added to the latex to ensure proper coagulation. Latex should be added in small amounts slowly and allowed to remain on the surface before stirring for about 20 seconds. Then, it should be stirred for 20 minutes to obtain a homogenous blend [30]. Ribbed Smoked Sheet (RSS) needs to be masticated with a two-roll mill at the temperature of $70{ }^{\circ} \mathrm{C}$ for 30 minutes and then cut into small pieces before being added to bitumen. The small pieces of RSS are added to virgin binder and mixed using a high shear mixer at a temperature of $150-170^{\circ} \mathrm{C}$ for 2 hours. The mixture is then incubated at a temperature of $120^{\circ} \mathrm{C}$ for one day. The properties of the rubberized binder and mixture should be tested for the different amount of RSS used [1].

\subsection{PROPERTIES OF NATURAL RUBBER}

Natural rubber has a special and unique physical and chemical properties which depends on the presence of non-rubber materials. Chemically, natural rubber latex is composed of hydrogen and carbon atoms, has a high molecular weight, and a chemical formula $\mathrm{C} 5 \mathrm{H} 8$. Polyisoprene can be produced synthetically since it has a double bond in each repeating unit. Adding sulphur into latex to improve raw rubber alters the thermoplastic elastomer properties of natural rubber into a thermoset [31]. Concerning its physical properties, natural rubber is typically elastic due to its high resilience and high stretch ratio. This is due to the complex molecular chains of polyisoprene, which forms almost linear chains under loading and return to its original position when the load is removed. The viscoelastic properties of rubber are also due to its combined liquid and solid characteristics. The properties of rubber is highly dependent on fillers and modifiers such as factice, carbon black, and whiting rather than the polymer itself $[26,32]$.

Pandian and Govindan [33] conducted a study in Mailam to compare the mechanical properties of raw natural rubber and carbon black field natural rubber composites. They observed that the hardness, tear strength and tensile strength of the carbon block are markedly higher than that of the raw natural rubber. The percentage of elongation of the carbon block was found to be lower than that of the raw rubber. This is an area which requires further investigation to find methods for overcoming the problem. Natural rubber is well- known for its elongation properties and excellent tensile strength.
It is also considered as one of the best polymers for use in bitumen modification by virtue of its higher compatibility, adhesiveness, reactive plasticizers, and coating properties [34].

\subsection{TYPES OF NATURAL RUBBER USED FOR BITUMEN MODIFICATION}

A review of previous studies, shows that natural rubber can be used as either Natural Rubber Latex, Liquid Natural Rubber, Ribbed Smoked Sheet (RSS) or Natural Rubber Powder, all of which has shown promising potential in improving the properties of asphalt mixtures. Further investigations need to be done on the use of natural rubber as rubberized bitumen in the effort to improve the performance and service life of asphalt pavements [26].

\subsection{Natural Rubber Latex (Field Latex)}

One of the ways to improve the performance of asphalt is by using natural rubber latex since it contains discrete rubber particles which easily fused with asphalt binder. Natural rubber latex acts as an elastic band during cold weather, which helps prevent the formation of cracks while at the same time retain asphalt stiffness. During hot weather, natural rubber acts as a film which improve shear resistance which subsequently prevents asphalt flow. The elastomer properties of natural rubber latex contributes significantly to improving long term pavement performance [26]. Field latex, on the other hand, contains about $36 \%$ rubber, a small amount of impurities and about $64 \%$ water. Field latex only can remain in liquid form for a maximum of up to three hours. There is a need to preserve latex as raw materials for natural rubber for long-term storage for future use in different applications [26, 28].

\subsection{Liquid Natural Rubber (LNR)}

Liquid Natural Rubber (LNR) is preferred over latex in the modification of bitumen since it blends better with the binder and produce a more homogeneous binder [35]. The availability of natural rubber in liquid form gives it a competitive advantage over synthetic rubbers, and this enhances the value and benefits of using natural rubber [26]. LNR can be produced by using peptizing agent prior to being heated in a depolymerizer.

\subsection{Ribbed Smoked Sheet (RSS)}

Ribbed Sheet (RS) is another form of the natural rubber used as an additive to enhance the performance of road pavements. Rubber sheet has its own unique shape, and form, and should be added to bitumen through a special method. Rubber sheet is suitable for combination with bitumen due to its lower water content. Rubber sheet is 
available as ribbed smoked sheet (RSS), block rubber (STR 20) and creep rubber [36]. RSS has been shown to produce acceptable improvement in the physical properties of virgin bitumen by decreasing penetration, softening point, torsional recovery and toughness_tenacity [1]. One disadvantage of using RSS to modify bitumen is that it resulted in less efficient product in comparison to using LNR to modify bitumen, which produces a more homogeneous product. This has an effect on the properties of bitumen as well as the performance of asphalt mixtures. RSS is also more expensive than LNR [26].

\subsection{Natural Rubber Powder (NRP)}

Natural rubber powder is another type of NR produced by extracting water from the raw material (latex). It is, however, not regularly used for bitumen modification. A study was conducted in Thailand to illustrate the preparation of natural rubber powder by using spray drying method. Water soluble modified starch of maltodextrin with DEl7 was used to encapsulate the latex particles which produces free flowing rubber powder. The study also investigated, the appropriate conditions of spray drying in the preparation of non-agglomerated rubber powder. The size and, distribution, as well as the morphology of the rubber particles were observed using SEM and laser light scattering technique, respectively. Results show that the optimum inner air temperature for producing rubber powder is $120^{\circ} \mathrm{C}$. The researchers also found that, in order to obtain free flowing rubber powder, the mass ratio of natural rubber to maltodextrin must not exceed 9:1 [37]. Natural rubber powder is less commonly used as it needs to be blended with bitumen at a high temperature for about 2 hours to obtain a homogenous product. Additionally, twice as much NR powder is required in comparison to latex. The powder form of natural rubber is more expensive than NR latex [19]. It is crucial to use natural rubber waste materials to reduce the cost of fixable pavement construction [38]. This is an area of research which focuses on discovering new techniques for extracting water from latex to further lower the cost modifying bitumen in comparison to the methods discussed above.

\subsection{PHYSICAL, RHEOLOGICAL AND CHEMICAL PROPERTIES OF NATURAL RUBBER MODIFIED BITUMEN}

The results of new studies have shown that adding rubber latex to bitumen will significantly improve the mechanical properties of modified binder [39]. Grumoorthy, T. [40] investigated the effects of LNR on bitumen properties and recommended that in depth research should be done to understand the behavior and effect of any polymer used to modify bitumen $[41,42]$. Many studies have been conducted to investigate the use of latex to improve the physical properties of bitumen. The most common methods used to investigate the rheological properties of bitumen are creep and cyclic (oscillatory) tests which will give a clear indication of the behavior of bitumen [43]. Fernando, M.J. and Nadarajah, M [11, 44] evaluated the results of using of raw latex rubber in the form of field latex, skim latex and concentrated latex. They found that using latex resulted in improvement in softening point and penetration. Vasaviswetha and Rani [21] conducted a study at the University of Andhra, India to evaluate the basic and rheological properties of rubberized bitumen and rubberized asphalt mixture. The natural rubber used in this study is natural rubber latex in the form of balloons. They found that using natural rubber in form of balloons improved the overall performance of asphalt mixtures and that natural rubber increases the service life of rubberized pavements by more than one hundred percent. They contended that incorporating natural rubber in pavements will result in reduced cost and higher safety.

A recent study has shown that increasing the amount of natural rubber additive in bitumen enhances the elastic recovery of bitumen [40, 45]. [18] investigated the effects of using natural rubber latex (DRC60) as a modifier on the physical properties of asphalt concrete wearing course. The study was conducted in compliance with the requirements set by the Indonesian National Standards, AASHTO, and ASTM. The physical properties of four sets of specimens, namely $0,2,4$ and $6 \%$ by weight of base bitumen, were investigated. Results show that the density of void filled with bitumen (VFB) in the asphalt concrete wearing course (ACWC) increased with higher latex content, which consequently improve the durability of the latex asphalt mixture. The optimum latex content of $4 \%$ produced the best improvement in the physical properties of the latex asphalt mixture. Another study has shown that adding higher amounts of NR resulted in better performance grade (PG) of non- rubberized binder where the bitumen becomes harder and more viscous. This results in improved stiffness and internal strength of the bitumen [8].

Al-Mansob et al. [15] investigated the physical and rheological properties of base bitumen $(80 / 100)$ modified with 2.36 mesh epoxidized natural rubber. Dynamic shear rheometer (DSR) was used to identify the rheological properties of the binder modified with varying amounts of ENR. Results show that increasing the amount of ENR resulted in reduced temperature susceptibility and increased viscosity, elastic behavior, and stiffness. They also found that the addition of ENR improved the rutting resistance of rubberized binder at high temperature. LNR reduced ductility and improved softening point. The researchers noted that an appropriate amount of LNR must be added to avoid high viscosity and low homogeneity. Results also show that the addition of LNR resulted in more viscous properties instead of elastic properties, while the physical properties of 
natural rubber deteriorate due to deploymerization. Natural rubber latex was also used to modify natural rubber in order to enhance the elasticity and plasticity of raw natural rubber [35].

Al-Khateeb and Ramadan [46] contended that using rubber sheets could affect road performance, such as higher viscosity, and improved durability and strength of road pavements. They found that rubber sheets prevent foaming and frothing during mixing with bitumen. A study conducted by Vichitcholchai et al. [1] showed that adding rubber sheets to bitumen resulted in higher strength and durability of road pavements in comparison to base bitumen. They also noted that amount of rubber sheet added must not exceed the content of rubber to avoid the loss of homogeneity of the mixture.

Polymer additives such as NR do not change the chemical nature of the bitumen being modified. However this needs to be investigated further to determine the effects of NR on the mechanical properties of bitumen and consequently the asphalt mixtures [2].

\subsection{PERFORMANCE OF NATURAL RUBBER MODIFIED ASPHALT MIXTURES}

Siswanto [18]conducted a study in Indonesia to evaluate the effect of natural rubber latex on the permanent deformation (rutting) of asphalt concrete wearing course (ACWC). Results show that latex increases the dynamic stability of asphalt mixture while simultaneously decreasing its rate of rutting. Kishore and Gottala [7] contended that rubberized binder shows good resistance rutting, and skid resistance. The addition of natural rubber also improve bitumen's resistance to drain down at higher temperature. Furthermore, the Marshall stability and flow properties of NR-modified asphalt mixture was enhanced and fulfilled the standard requirements at $4 \%$ NR. Natural rubber improves the low temperature cracks resistance of binders. Rubberized asphalt mixtures show better overall performance, and this results in a better fixable pavement in terms of service life and safety. Natural rubber improved the performance and service life roads by more than $100 \%$ when compared to non-rubberized roads. Krishnapriya [47] stated that using natural rubber as a modifier in asphalt mixtures results in improved rut resistance, resilient modulus, and fatigue life of asphalt mixtures.

Shaffie et al. [27] examined the effects of natural rubber on the stripping performance of asphalt mixtures. They observed improvement in the physical properties of bitumen as well as superior overall pavement performance. A new study was carried out to investigate the rutting performance of two types of asphalt mixtures, namely dense graded (AC) and stone mastic asphalt (SMA) [12]. The study also aimed to determine the optimum amount of additive to be used in the mixing process. Two types of bitumen were evaluated, 80/100 penetration grade and PG76 performance grade. Results show that both dense graded and SMA mixtures with nanocomposite conformed with the Marshall volumetric criteria which indicates the durability of both mixtures. In terms of Marshal stability and flow properties, there was an improvement and both mixtures fulfilled the Malaysian Public Works Department (PWD) specification requirements. The rutting performance of SMAl4 added with the modifier ranges from $0.8 \mathrm{~mm}$ to $1.9 \mathrm{~mm}$ and that of ACl 4 ranges from $1.7 \mathrm{~mm}$ to $2.3 \mathrm{~mm}$; this indicates the benefit of using nanocomposite polymer, especially with the SMA14 mixture. Ali et al. [8] found that increasing the amount of NR in bitumen results in improved overall performance of asphalt mixtures. They also noted that the addition of higher amounts of natural rubber resulted in higher stiffness modulus and lower creep. Hence, natural rubber has a promising potential to improve the performance of flexible pavements.

A study was carried out in India to evaluate the performance of natural rubber modified asphalt mixtures. Results show that the specimens prepared with medium gradation produced better results than other specimens. The NR-modified asphalt mixture shows excellent stability and flow characterizations compared to the control sample. It was also found that the rut resistance of modified asphalt mixture significantly improved. The results of repeated load test show that the fatigue life of rubberized asphalt mixture increased with higher resilient modulus and lower air void and initial strain of the mixture. In summary, NRMAM shows a better overall performance when compared with conventional asphalt mixture [47]. The density of void filled with bitumen (VFB) in ACWC increases with higher latex content, which results in improved durability of the latex asphalt mixture. An optimum latex content of $4 \%$ produced the best improvement in the physical properties of the latex asphalt mixture [30]. The use of polymers as additive affect the permeability and drain down of a mixture, which in turn affect the volumetric and adhesion properties of the mixture $[48,49]$.

\subsection{COST OF USING NATURAL RUBBER FOR BITUMEN MODIFICATION}

A study was conducted in Thailand [50] to analyze the price behavior of natural rubber latex. Results show that the demand for natural rubber around the world is increasing rapidly with better living standard and economic advancement. The price of NR is the main factor affecting the livelihoods of rubber growers. It was also stated that synthetic rubber is a petroleum based product with high value fluctuation. In this way, there is an extreme interest for natural rubber around the globe to be used as a sustainable option in various applications. The value strength has 
an immediate beneficial outcome on the laborers and gainfulness income. In contrast, uncertainties in natural rubber price adversely affect the finance of NR based industries. Hence, the fluctuation of NR price plays a significant role in the livelihood of millions of tappers and small rubber growing households around the world. It was presumed that stainability of the NR business is noteworthy for monetary through the creation of large number of employments and foreign receipts income. In this way, change of NR cost may negatively affect for both natural and monetary strategies. Azahar et al. ([26] conducted a general review of the use of natural rubber for bitumen modification. They contended that the low price of natural rubber that are locally sourced compared with the price of other polymers have motivated governments around the world to study the feasibility of using it as an alternative for bitumen modification.

From the authors of this paper perspective, a costbenefit ratio analysis should be carried out to establish the ideal amount of natural rubber that can be used to overcome long term fatigue and rutting resistance of the asphalt mixture as bitumen modifiers in regions and countries which produced the natural rubber such as Malaysia. It is expected that using a natural rubber as an alternative additive will not only improve the fatigue and rutting performance of the asphalt mixtures but from environment view point, it can be utilized for sustainable construction and cost effective. Similarly, natural rubber found locally are highly promising alternatives and less expensive in contrast to the commercially available modifiers used in asphalt binder solely for the mitigation of distresses due to rutting and fatigue in bituminous mixtures. The natural rubber mixed with bitumen can reduce maintenance cost as well as pavement distresses. The expected use of NR may reach up to 4.5 tonnes of dried rubber per kilometer per lane.

\subsection{CONCLUSION}

The increasing in traffic volume and higher traffic load brings challenges to the construction of roads; this is compounded by insufficient repair and maintenance work which have resulted in failure and reduced service life of roads. The properties and behavior of bitumen are related to loading period and temperature $[6,7,26]$. In tropical countries, bitumen tends to be soft and more liquid as temperature increases, and this results in poor viscoelastic and rheological properties of the bitumen, thereby causing distress, such as permanent deformation (rutting), on road surface [26]. In cold regions, on the other hand, bitumen turns hard and stiff, and this results in higher brittleness, thereby causing fatigue distress. A number of previous studies have shown that conventional bitumen experiences high pavement distress, especially rutting, fatigue failure and moisture damage. [51, 52]. These problems have motivated researchers in the field of the highway and pavement engineering to find methods to solve the problems related with pavement distresses. Natural rubber is a sustainable alternative for petroleum-based modifiers since it is locally produced, environmentally friendly and low price fluctuation compared to petroleum-based modifiers. Therefore, the researchers hope to develop a cost effective and long-lasting natural rubber modified flexible road pavements which would also be fatigue and rut resistant. This will reduce the amount of work and expenditure required for the annual maintenance of asphalt mixtures around the world.

\section{Acknowledgement}

The authors would like to express their gratitude to Universiti Kebangsaan Malaysia (UKM) (DIP-2017-004) and Universiti Teknologi PETRONAS (UTP) for the support of this work.

\section{References}

[1] Vichitcholchai, N., Panmai, J. and Na-Ranong, N. 2012. Modification of Asphalt Cement by Natural Rubber for Pavement Construction. Rubber Thai Journal. 79(3): 32-39.

[2] KRISHNAPRIYA, M. 2015. Performance Evaluation of Natural Rubber Modified Bituminous Mixes. International Journal of Civil, Structural, Environmental and Infrastructure Engineering Research and Development (IJCSEIERD). 5 (34): 121-134.

[3] Lu, X. and Isacsson, U. 2000. Laboratory Study on the Low Temperature Physical Hardening of Conventional and Polymer Modified Bitumens. Construction and Building Materials. 14(2): 79-88.

[4] Han, J. W., Lee, S. K., Yu, C. and Park, C. G. 2015. Effect of Rapid Set Binder on Early Strength and Permeability of HES Latex Modified Road Repair Pre-packed Concrete. 4th Global Conference on Materials Science and Engineering (CMSE 2015): IOP. 103: 012007.

[5] Tayfur, S., Ozen, H. and Aksoy, A. 2007. Investigation of Rutting Performance of Asphalt Mixtures Containing Polymer Modifiers. Construction and Building Materials. $21(2)$ : 328-337.

[6] Murphy, M., O'mahony, M., Lycett, C. and Jamieson, I. 2000. Bitumens Modified with Recycled Polymers. Materials and Structures. 33(7): 438-444.

[7] Kishore, K. S. N. and Gottala, A. 2015. A Study on Effect of Addition of Natural Rubber on the Properties of Bitumen \& Bituminous Mixes. IJSTE - International Journal of Science Technology \& Engineering. 2(1): 206-212.

[8] Ali, S. A., bin Yusof, I., Hermadi, M., Alfergani, M. B. and Ab Sinusi, A. 2013. Pavement Performance with Carbon Black and Natural Rubber (Latex). International Journal of Engineering and Advanced Technology. 2(3): 124-129.

[9] Y., B., P.M. M., and R. Y. 2001. Polymer Modified Asphalt. Vision Tecnologica. 9: 39-50.

[10] Sengoz, B. and Isikyakar, G. 2008. Evaluation of the Properties and Microstructure of SBS and EVA: Polymer Modified Bitumen. Construction and Building Materials. 22(9): 1897-1905.

[11] Ibeagi, U. M., Okereke, S. O. E., Okpareke, O. C. and Ukoha, P. O. 2012. Studies on the Modifications of Asphalt Binder Using Some Selected Polymers. International Journal of Chemical Sciences. 10(4): 2048-2056. 
[12] Shaffie, E., Ahmad, J., Arshad, A.K., Kamarun, D. and Awang, H. 2016. Investigation on Rutting Performance of Nanopolyacrylate and Natural Rubber Latex Polymer Modified Asphalt Binder Mixes. Jurnal Teknologi. 78(7-3): $11-15$.

[13] Y., W., U. P., and P. H. 2014. A Study of Greenhouse Gas Emissions from Rubber Tree Plantations in Rayong Province. The 1st Environment and Natural Resources International Conference, Bangkok, Thailand.

[14] Islam M. A. E. 2014. Performance of Asphalt Mixes Containing Rubber. International Journal of Civil Engineering \& Technology (IJCIET). 5(7): 7-16.

[15] Al-Mansob, R. A., Ismail, A., Alduri, A. N., Azhari, C. H. Karim, M. R. and Yusoff, N. I. M. 2014. Physical and Rheological Properties of Epoxidized Natural Rubber Modified Bitumens. Construction and Building Materials. 63: 242-248.

[16] Al-Mansob, R. A., Ismail, A., Yusoff, N. I. M., Azhari, C. H., Karim, M. R., Alduri, A. and Baghini, M. S. 2014. Rheological Characteristics of Epoxidized Natural Rubber Modified Bitumen. Applied Mechanics and Materials. 505: 174-179.

[17] Tuntiworawit, N. Lavansiri, D. Phromsorn, C. Engineer, C. 2005. The Modification of Asphalt with Natural Rubber Latex. Proceedings of the Eastern Asia Society for Transportation Studies.

[18] Siswanto, H. 2017. The Effect of Latex on Permanent Deformation of Asphalt Concrete Wearing Course. Procedia Engineering. 171: 1390-1394.

[19] Ruggles, C. S. 2004. The Efficient Use of EnvironmentallyFriendly Natural Rubber Latex in Road Construction-Past, Present and the Future. Rubber in Transport: Breda, The Netherlands.

[20] Al-Mansob, R. A., Ismail, A., Yusoff, N. I. M., Rahmat, R. A. O., Borhan, M. N., Albrka, S. I., Azhari, C. H. and Karim, M. R. 2017. Engineering Characterisation of Epoxidized Natural Rubber-modified Hot-mix Asphalt. Plos One. 12(2): p.e0171648.

[21] Swetha, D. V. and Rani, K. D. 2014. Effect of Natural Rubber on the Properties of Bitumen and Bituminious Mixes. International Journal of Civil Engineering and Technology. 5(10): 9-21.

[22] Tantatherdtam, R. 2003. Reinforcement of Natural Rubber Latex by Nanosize Montmorillonite Clay. Department of Materials Science and Engineering. The Pennsylvania State University.

[23] Ismail, H. and Salmah, M. N. 2001. Dynamic Vulcanization of Rubberwood-filled Polypropylene/Natural Rubber Blends. Polymer Testing. 20(7): 819-823.

[24] Francken, L. 2004. Bituminous Binders and Mixes. CRC Press. 7.

[25] Wen, Y., Wang, Y., Zhao, K. and Sumalee, A. 2017. The Use of Natural Rubber Latex as a Renewable and Sustainable Modifier of Asphalt Binder. International Journal of Pavement Engineering. 18(6): 547-559.

[26] Azahar, N. F. B. M., Hassan, N. B. A., Jaya, R. P., Kadir, M. A. B. A., Yunus, N. Z. B. M. and Mahmud, M. Z. H. 2016. An Overview on Natural Rubber Application for Asphalt Modification. Int J Agric for Plant. 2: 212.

[27] Shaffie, E., Ahmad, J., Arshad, A. K., Kamarun, D. and Kamaruddin, F. 2015. Stripping Performance and Volumetric Properties Evaluation of Hot Mix Asphalt (HMA) Mix Design Using Natural Rubber Latex Polymer Modified Binder (NRMB). InCIEC 2014. Springer, Singapore: 873-884.

[28] Kumara, P. S. 2006. Methods of Estimation of Dry Rubber Content in Natural Rubber Latex. Bulletin of Rubber Research Institute of Sri Lanka. 47: 65-69.

[29] Azahar, N. F. B. M., Hassan, N. B. A., Jaya, R. P., Kadir, M. A. B. A., Yunus, N. Z. B. M. and Mahmud, M. Z. H. 2016. An Overview on Natural Rubber Application for Asphalt Modification. Int J Agric For Plant. 2: 212.

[30] Siswanto, H. 2016. Improving the Physical Properties of Asphalt Concrete Wearing Course Using Latex DRC60. Proceedings of the International Mechanical Engineering and Engineering Education Conferences (IMEEEC). Indonesia: AIP Publishing.

[31] Thomas, S., Chan, C. H., Pothen, L. A., Rajisha, K. R. and Maria, H. eds. 2013. Natural Rubber Materials. Blends and IPNs (Vol. 7). Royal Society of Chemistry.

[32] Kim, J. H. and Jeong, H. Y. 2004. Effects of Carbon Black on the Fatigue Life, Critical J-Value and Fracture Morphology and a New Estimated Equation for Natural Rubber. KSME International Journal. 18(6): 915-923.

[33] Pandian, J. J. and Govindan, T. 2015. Comparative Studies on the Mechanical Properties of Natural Rubber and Natural Rubber Carbon Black Composites. International Journal of Emerging Technology in Computer Science \& Electronics (IJETCSE). 13(2): 48-52.

[34] Ibrahim, S., Daik, R. and Abdullah, I. 2014. Functionalization of Liquid Natural Rubber via Oxidative Degradation of Natural Rubber. Polymers. 6(12): 2928-2941.

[35] Okieimen, F. E. and Akinlabi, A. K. 2002. Processing Characteristics and Physicomechanical Properties of Natural Rubber and Liquid Natural Rubber Blends. Journal of Applied Polymer Science. 85(5): 1070-1076.

[36] Jawjit, W., Kroeze, C. and Rattanapan, S. 2010. Greenhouse Gas Emissions from Rubber Industry in Thailand. Journal of Cleaner Production. 18(5): 403-41 1.

[37] P., S. and S. A. 2011. Preparation of Natural Rubber Powder by Spray Drying. TIChE International Conference 2011. Hatyai, Songkhla THAILAND.

[38] Kishchynskyi, S., Nagaychuk, V. and Bezuglyi, A. 2016. Improving Quality and Durability of Bitumen and Asphalt Concrete by Modification Using Recycled Polyethylene Based Polymer Composition. Procedia Engineering. 143: 119-127.

[39] Dong, X., Wang, S., Gong, C. and Lu, L. 2014. Effects of Aggregate Gradation and Polymer Modifiers on Properties of Cement-EPS/vitrified Microsphere Mortar. Construction and Building Materials. 73: 255-260.

[40] Tinavallie, G., 2013. Improving the Ductility and Elastic Recovery of Bitumen-natural Rubber Latex Blend. Department of Chemical Science, Faculty of Science. Doctoral Dissertation. Universiti Tunku Abdul Rahman: Malaysia. 164

[41] Yusoff, N. I. M., Jakarni, F. M., Nguyen, V. H., Hainin, M. R. and Airey, G. D. 2013. Modelling The Rheological Properties of Bituminous Binders using Mathematical Equations. Construction and Building Materials. 40: 174188.

[42] Yusoff, N. I. M., Mounier, D., Marc-Stéphane, G., Hainin, M. R., Airey, G. D. and Di Benedetto, H. 2013. Modelling the Rheological Properties of Bituminous Binders using the 2S2P1D Model. Construction and Building Materials. 38: 395-406.

[43] Yusoff, N. I. M., Shaw, M. T. and Airey, G. D. 2011. Modelling the Linear Viscoelastic Rheological Properties of Bituminous Binders. Construction and Building Materials. 25(5): 2171-2189.

[44] Fernando, M. J. and Nadarajah, M. 1969. Use of Natural Rubber Latex in Road Construction. Rubber Res Inst Malaya J. 22(5): 430-440.

[45] Khadivar, A. and Kavussi, A. 2013. Rheological Characteristics of SBR and NR polymer Modified Bitumen Emulsions at Average Pavement Temperatures. Construction and Building Materials. 47: 1099-1 105.

[46] Al-Khateeb, G. G. and Ramadan, K. Z. 2015. Investigation of the Effect of Rubber on Rheological Properties of Asphalt Binders Using Superpave DSR. KSCE Journal of Civil Engineering. 19(1): 127-135.

[47] Krishnapriya, M. G. 2015. Performance Evaluation of Natural Rubber Modified Bituminous Mixes. International Journal of Civil, Structural, Environmental and Infrastructure Engineering Research and Development (IJCSEIERD). 5(1): 121-134.

[48] Zhang, Y. and Kong, X. 2014. Influences of Superplasticizer, Polymer Latexes and Asphalt Emulsions on the Pore 
Structure and Impermeability of Hardened Cementitious Materials. Construction and Building Materials. 53: 392-402.

[49] Han, J. W., Jeon, J. H. and Park, C. G. 2015. Mechanical and Permeability Characteristics of Latex-modified Prepacked Pavement Repair Concrete as a Function of the Rapid-set Binder Content. Materials. 8(10): 6728-6737.

[50] Neupane, H. S. and Calkins, P. 2013. An Empirical Analysis of Price Behavior of Natural Rubber Latex: A Case of Central Rubber Market Hat Yai, Songkhla, Thailand.
Uncertainty Analysis in Econometrics with Applications: 185-201. Springer, Berlin, Heidelberg.

[51] Al-ani, T. M. 2009. Modification of Asphalt Mixture Performance by Rubber-Silicone Additive. Anbar Journal for Engineering Sciences. 2(1): 71-81.

[52] Chen, X. and Huang, B. 2008. Evaluation of Moisture Damage in Hot Mix Asphalt Using Simple Performance and Superpave Indirect Tensile Tests. Construction and Building Materials. 22(9): 1950-1962. 